This work is licensed under a Creative Commons Attribution 4.0 International License.

Ovaj rad dostupan je za upotrebu pod licencom Creative Commons Imenovanje 4.0 međunarodna.

Faculty of Humanities and Social Sciences

University of Zagreb

DOI: https://doi.org/10.29162/ANAFORA.v6i2.7

Ivana Lučića 3, HR - 10000 Zagreb

sgrgas@ffzg.hr

Izvorni znanstveni članak

Original Research Article

Primljeno 18. prosinca 2018.

Received: 18 December 2018

Prihvaćeno 2. travnja 2019.

Accepted: 2 April 2019

\title{
UNIFORMITY AND DIFFERENCE OF AGEING
}

\begin{abstract}
"He said, think of life as a novel, let's say a novel of four hundred pages, and then imagine how many pages in the book your story has already covered."
\end{abstract}

(Rushdie 225)

\begin{abstract}
"Now he was fifty-four years old and was as intriguing to corporate America as an airplane built from mud." (Eggers 11)
\end{abstract}

\begin{abstract}
The author proposes that ageing and old age can be seen as a universal process but also as something that can be differentiated both by time and place. In the central part of the article, the author contends that one way of approaching the topic, particularly if it is addressed as part of the United States polity, is through the lens of American Studies and, more specifically, through the work of R.W.B. Lewis and his idea of the American Adam. It is precisely the self-image of the United States as a country of youth that elides the significance of ageing from the disciplinary agenda. In addition, the author contends that the American socio-economic order marginalizes ageing as incompatible with its dynamics. In the conclusion, the author up-
\end{abstract}


dates the issue and shows how today's pension schemes affect what was precisely designated as a time of retirement.

Keywords: ageing, American Studies, American Adam, youth, Trump, R.W.B. Lewis

\section{Introduction}

Old age is and is not a socio-cultural construct. The extent that it is not a construct is brought forward by its foregrounding of the individual experiencing of body and mind. As an existential predicament, old age is the prerogative of old people and as such is a universal category. However, here at the very beginning we encounter a difficulty. Namely, the question when is one old does not yield a uniform answer but is geographically and historically differentiated. One needs only look at the world's life expectancy statistics to realize that what is defined as old age evinces variations according to country and region. The same holds true for the variations at what point old age was demarcated in different historical periods. Looking back on my own life span, I can say that what was considered old has changed. Years have been added to what was once deemed to be old age, changes imposed on how it is to be lived and how, if at all, it is to be spoken about.

There are very few privileges attending to old age. One such is that one is able to see through and put to question new quantifications and qualifications of old age and to view these as strategies that are not endogenous to old age itself. I would go so far as to say that old age can barely speak and that if it does speak it does so through venues not of its own making. On occasions when I have witnessed it being addressed, old age was regularly ventriloquized by those who were still spared its weight. Yet, it is not easy to speak of old age even if the one speaking is old by default. I use the last phrase because I think there is very little substance, except finality, that can be attributed to old age and that we as a rule define it in relational terms, namely as the antipode of youth. The relational definition of ageing and old age is particularly relevant in a scholarly field, meaning American Studies here, where these topics are conspicuous by their absence. In order to substantiate that claim, in what follows I will briefly remark on that absence and offer the antipodal image of a "forever young" nation as a ground for thinking ageing in American Studies. I will proceed by showing that the valorizations of youth and old age are not merely confined to the sphere of self-representations but that they belong to a temporality that is an indispensa- 
ble factor in the United States socio-economic assemblage. If there is a dearth or absence of material signifying how ageing fares in the United States and in American Studies, this does not mean that we cannot address the matter by way of a detour precisely through American Studies. That detour will comprise the bulk of this paper.

1.

Embarking on that detour, let me first address, as a preparatory step, what I see as the privileging of spatiality in American Studies. If we recall most of the founding paradigms of the discipline - wilderness, west, city, bridge, road, to name but some of them - we recognize that they refer to space. It is as though American Studies experienced the "spatial turn" even before its heyday during the last decades of the twentieth century. Conceding that I have myself frequently relied on spatial concepts and metaphors in explaining American experience, I take to heart Jon May's and Nigel Thrift's warning that the "spatial turn" has produced a new fundamentalism that simply overturns the dualism of space and time and that we ought to embrace the "more complex notion of TimeSpace" (1). One or two generalizations about American capitalism, the background assemblage on which much of what I will be saying has to be seen, will indicate how that more complex notion can be used. I have in mind, for example, the argument that the development of capitalism in America was determined by the absence of a feudal past. I will add to this the opinions of those who maintain that unhampered, expansionist development in the United States was enabled by the availability of vacant land.

On different occasions, I have expressed my agreement with these interpretations but now I see the need to supplement them with the contention that American capitalism also worked with and promulgated a distinct temporality. That temporality was unencumbered by the past and expansionist, growth- and future-oriented. That temporality has no truck with the past, which can only hamper its projections that are concocted and implemented upon the belief in the feasibility of unlimited accumulation. Of course, that temporality brackets off the evidence of the past, which, if attended to, points to limiting obstacles and the possibility of unwanted outcomes. As such, that temporality subtends an ideology of capitalism and is not the historical trajectory of capitalism as such. William H. Sewell shows how the temporality of capitalism is plural. On the one hand, there is something "almost uncannily, repetitive" in the business 
cycle (Sewell 519) while, on the other, there is "capitalism's powerful and consistent drive towards expansion" (Sewell 521). If we were to map the history of capitalism in the United States, the repetitions of crises would be a substantial part of that account but if our purpose is to understand the capitalist spirit, the understanding of time through which the United States almost identifies with capitalism, that evidence is downplayed. It is downplayed because the evidence of past bubbles, crises, and recessions would function as warning signs in any kind of decision-making, paralyzing the forward drive of developmental logic. Needless to say, the temporality that is inaugurated as the driving force of development, investment, and growth is promulgated not though logic and evidence but through images and other modes of representation. On the content level, one of the ways that it is promulgated is through the disparagement and elision of ageing and old age and the celebration of youth and its denizens.

To sum up the argument so far: on one level, old age, as a visceral, highly personal, experience, can hardly be shared with others. Amongst old age-mates, it is hardly the most favorite topic, while to those who are not sharing the experience it is irrelevant, uninteresting or simply boring. In my opinion, it is only by a stretch of the imagination that this always individualized experience can be made the subject matter of inter-personal, cross-generational scholarly interest. Yet, as already said, ageing and old age are not something unchangeable, something per se, but both the process and the final outcome are embedded in historical-social conditions. To put this otherwise, the person ageing is not only an individual but he or she experiences the process of ageing in his or her collectivity, as a member of a family, as a citizen of a state and as a body in the economic processes of production and circulation. Since my remarks on ageing are being made within the field of American Studies that, if anything, holds that there exists a differentiated object of research and teaching, namely the United States, it would seem that ageing as something universal, something that is shared by mankind in general has only a tangential bearing on what Americanists do or how they particularize this universal. However, as I will explain below, registering the position from which I am writing, the American conceptualization and valorization of old age are part and parcel of the world that America is shaping in its image. This helps us understand our local predicament. Furthermore, if that image both on America's domestic front but also abroad elides ageing, old age and death, this does not prevent us from contending that these facilities constitute the radical other of the identity constructions of American Studies. 
Although circumspection concerning ageing and death is something that permeates human experience as such, I am proposing the notion that it was the erasure of ageing as a human given that was an enabler in the formation of a distinct American temporality whose virility is nowadays attested by its global reach.

Even a cursory review of the relevant literature leads to the conclusion that ageing and old age have not been a top research priority in American Studies. A rare foray into the problematic was a collection of articles published by Hartung and Kunow (2011). In their introduction to the volume, they explicitly note that "very rarely in American Studies" does one find people addressing ageing. They do not delve deeper into why this is the case but do summarize that the contributors to their volume "discuss how U.S. culture constitutes a framework of discursive practices and also provides a vocabulary in which the problems of the elderly emerge, are constructed, (mis-)represented, or even silenced" (Hartung and Kunow 15). Although I am not dealing here with problems of the elderly, except perhaps in the brief concluding section of this paper, I believe that my remarks contribute to an understanding of the construction and misrepresentation of ageing in the United States and why it is so often silenced.

My point of departure is not empirical, although my standpoint is that of an empirically verifiable old man, but rather the proposition that there exist overriding structures of ordering time that are characteristic of different human collectivities. Thus, considering the American socio-economic order outlined above and the very discipline of American Studies, it seems to me that the elision of ageing from interpretations of the American experience is almost inevitable. Looking back on the archive of American Studies in search of reasons for this elision, one has only to mention R.W.B. Lewis's book The American Adam (1955). Although Lewis's study is much more complex than the way his title has been made to function as a shibboleth referencing this or that aspect of American experience, in my opinion it does focus upon a specificity of American temporality that has been repeatedly privileged in the self-representations of the American polity. Before going to the book itself, I will outline a broader context for reading the American Adam.

Philosophizing old age, Jan Baars, drawing upon Adorno's and Horkheimer's argument in Dialectic of Enlightenment (1972), points to man's fear of being 
overwhelmed by nature and his desire to control it. According to Baars, as long as the aging process remains uncontrollable,

the striving for complete technological control is continually confronted with mankind's shortcomings, which explains why those who are reminders of this tragic failure tend to be excluded. It comes as no surprise that a society focused on being young, dynamic, and "in control" is at a loss where aging is concerned.

The society that is evoked in the last sentence, young, dynamic, and in control can easily be said to be epitomized by the United States. This should come as no surprise since the American project was in so many ways put forward as the embodiment of the Enlightenment. The dynamic nature of that polity, the pride it takes in technological prowess, and, most importantly, its self-projections and representations as a country that is "forever young" will readily be recognized as characteristics that have been explored by American Studies.

To update the said context, we can say that the American polity is able to confront the facticity of ageing even less at a time when control, to isolate one of Baars's terms, has intensified and when thinking itself has been displaced as an activity. In his book Late Capitalism and the Ends of Sleep (2014), Jonathan Crary designates our times as a time when "billions of dollars are spent every year researching ... how to eliminate the useless time of reflection and contemplation" (40); according to Crary "the form of contemporary progress is the relentless capture and control of time and experience" (40). As a corollary, I add that ageing relentlessly does otherwise and outflanks and shows the vanity of all attempts to put time under control. In such a constellation, one of the things that is displaced is death and the useless reflection, to paraphrase Crary, on death. From another perspective, Paul Connerton comments on how the planned obsolescence of fashion elides death from human consciousness:

What is fashionable disappears as quickly as it appears; its ephemeral attractiveness incubates the seeds of its own death. In an age when fashion precipitates many transient little manufactured deaths, persons find it difficult to deal with their natural future: their own death. There is an inverse relationship between the neophilia of fashion and the taboo on speaking of death. (61) 
Put forthrightly, ageing and death are simply not fashionable in the present conjuncture that is so powerfully stamped by the American way of experiencing and doing things. To anticipate what will shortly follow, I will add that ageing and old age are simply bad for business. Connerton goes to Lukacs to explain how forgetting, forgetting the inevitability of ageing and death I would add, is a necessity in the capitalist process of production, which is "constituted by the loss of its memory of the very process through which it is produced" (43). He also adds: "As an organized structure of misrecognition, it [the capitalist process of production] blocked access to recollection of the past processes which erected it and maintained it in being" (Connerton 43). The significance of this cannot be overstated and above I remarked how it is manifest in capitalist temporality. Here, I will add that if we accept that we are witnessing the Americanization of the planet and the triumph of capitalism, it is then necessary to recognize that these processes do not only have a spatial dimension but are also manifest in the imposition of a distinct temporality. That temporality ousts "vernacular," to use Ivan Illich's term, temporalities and practices. Returning to the notion of "timespace," I contend that if spatiality is inherent in the portrayal of American expansionism as a topic endemic to American Studies, that spatiality has to be seen as imbricated into a certain temporality.

2.

The 2010 EAAS Biennial Conference held in Dublin, which was titled "Forever Young? The Changing Images of America" and the published collection of essays that came out of it (Coleman and Matterson 2012), regardless of the question mark in the title, evinced the abiding power of America's youthful self-image, if only as a departure point for (re)thinking the United States. This is particularly true if we focus on the structural specificity of American temporality and not on this or that aspect of either youth or old age. In her contribution to the volume of essays, dealing with the lifestyles of America's ageing population, Eva-Sabine Zehelein does mention "negations of age and ageing, and attempts to deny one's mortality" (24). Susan Castillo Street notes that " $\mathrm{t}] \mathrm{he}$ notion of America as an exceptional, an eternally youthful nation that is somehow beyond time, contingency and, one might argue, historical responsibility, is profoundly seductive" (119). In the same paragraph, Castillo Street mentions the idea of America "as eternally youthful nation" (119) and its "flight from the 
past" (119). These remarks are more to the point of my argument than other sociological, demographic, and historical accounts assembled in Coleman's and Matterson's collection because I am approaching the issue of ageing from American Studies and not from any individual discipline. Thus, it is strange that none of the contributors to the collection mention R.W.B. Lewis whose "American Adam," in my opinion, deserved to be the starting point of the whole discussion concerning youth. Of course, there is the possibility that Lewis is taken for granted although other references that are mentioned in the collected articles hold similar positions in the archive of American Studies. I will briefly turn to Lewis because I hold that his is the most important contribution to the topic of youth in American Studies. My use of Lewis seeks to prove that some tenets of the discipline of American Studies, despite revisionist interventions, do not age but continue to be relevant.

In his book The American Adam (1955), Lewis wrote of "the case against the past" (13) as constituting the radical new personality of the American. A quote from his Prologue will remind us what American Studies sought to do in its youth:

The new habits to be engendered on the new American scene were suggested by the image of a radically new personality, the hero of the new adventure: an individual emancipated from history, happily bereft of ancestry, untouched and undefiled by the usual inheritances of family and race; an individual standing alone, self-reliant and self-propelling, ready to confront whatever awaited him with the aid of his own unique and inherent resources. (5)

In one word: a figure of youth, an antithesis of everything that old age stood for. In this "hopeful creed," America "had no past, but only a present and a future" (Lewis 7). This espousal of the doctrine of "the sovereignty of the living" (15), as Lewis named it, prescribed that "everything associated with the past should be burned away. The past should be cast off like dead skin" (21). As readers of Lewis know, this disavowal of the past is only one of the trajectories that the American polity took after it had positioned itself against old Europe in its work of identity formation. Yet, it was the one that, I hold, can be traced in numerous accounts of the American experience and that continues to have a relevance in the contemporary world. Even if back in the fifties Lewis, speaking for the polity, had written that "we direct our tired attention to the burden of 
history, observing repeatedly that it is later than you think" (196), the tenacity of the self-representation of the United States as a "forever young" nation is far from having disappeared. Lewis himself was aware of that possibility: "We can hardly expect to be persuaded any longer by the historic dream of the new Adam. But it can pose anew ... the picture of what might be against the knowledge of what is" (10). Below I address two recent reincarnations of the myth of the American Adam.

The first made its appearance in 2008 when Barack Obama was elected president and was hailed as the embodiment of the new American Adam. I quote Justine Toh:

That is the soul of America: the hope and optimism not only associated with change, but new beginnings . . Obama is the latest incarnation of that process for reinvention and self-renewal ... Obama manifests the possibility of racial harmony, inspiring leadership, global responsibility, and above all, a departure from the old - associated with the vastly unpopular George W. Bush Administration (2001-9). Obama, in contrast, represents the radically new, although he does so by embodying a familiar, uniquely American theme, the "American Adam."

Let me specify: the radical newness of Barack Obama had less to do with the reality of his politics than with the rhetoric and representations of his presidency. However, what cannot be gainsaid is that his election had a great deal to do with the redeployment of the myth of the American Adam and, I would add, with the displacement of what was deemed ageing and old. No such redeployment of the myth attended Donald Trump's election in 2016. I cannot recall uses of the myth in his campaign or afterwards. In not using it, one would surmise that Trump was adhering to facts both regarding the truth value of myth and his own age. Yet, this is not to be expected from the incumbent American president and I corroborate this assertion by quoting a situation in Wolff's book Fire and Fury (2018). In the book, on the occasion of Trump's first act as president, his visiting the CIA headquarters, we read the following tirade:

You know when I was young. Of course I feel young - I feel like I was 30 ...35 ... 39 ... Somebody said, Are you young? I said, I think I'm young. I was stopping in the final months of the campaign, four stops, five stops, seven stops - speeches, speeches in front of twenty-five, thirty thousand people ... fifteen, nineteen thousand. I feel young - I think we're all so 
young. When I was young we were always winning things in this country. We'd win with trade, we'd win with wars - at a certain age I remember hearing from one of my instructors, the United States has never lost a war. And then, after that, it's like we haven't won anything. You know the old expression, to the victor belongs the spoils? You remember, I always say, keep the oil. (Wolff 48)

The shift from the first person past tense of the opening sentence to Trump's rambling about how he feels and thinks he is young, to his pronouncement on the collectivity ("all so young") testifies to the tenacity of the myth of youth and how it goes against the knowledge of what is. The difference between Obama and Trump is that unlike Obama being hailed as the latest American Adam by others, Trump himself does all the work of interpellating himself into the American myth of unending youth. To the point of these purchases on the American Adam is Ihab Hassan's succinct observation regarding the American protagonist in literature: "His innocence ... is a property of the mythic American self, perhaps of every anarchic Self. It is the innocence of a Self that refuses to accept the immitigable rule of reality, including death, an aboriginal Self the radical imperatives of whose freedom cannot be stifled" (6). What Hassan found in American literature not only finds embodiment in other spheres of American culture and society but is a product of the American ideology of time.

Recognizing the absence of evidence for ageing and old age in American Studies, I did not undertake a search that would have provided such evidence and proved that despite all it does exist. Rather, I used the pronouncements on youth as counterfactual evidence, which by their very insistence indicate the power of what is absent. Put otherwise, ageing and old age are always lurking in the discourse of youth. In this way, I think, I have given a new lease of life to a reading of American experience, Lewis's, which in our haste we might proclaim antiquated and obsolete. I hope to have shown that it still has a heuristic potential. That potential does not only help us understand the structures of American temporality but also the grotesque scene of an old president rambling about youth. During his visit to the CIA headquarters, Donald Trump dramatized the mythic American self's refusal of the immitigable rule of ageing, to rephrase Hassan a bit, refusing to acknowledge the reality principle and the universal, all too human, inevitability of time passing and of death. But such are the president's prerogatives. The vast majority of other individuals facing that inevitability find themselves, as elders, in a state of obsolescence. Paraphrasing 
my epigraph from Dave Eggers, when old, we are as intriguing to the economic system as an airplane built from mud. Whatever experience we have accumulated, whatever skills or knowledge we possess, all of these and much more are no longer solicited. ${ }^{1}$ In polite parlance, we are retired. However, that universal first person plural is marked by differences both when we look at the state of retirement during various historical stages but also if we look at the state of retirees from different places in the present conjuncture.

Those differences are not endogenous to old age. Rather they must be understood as registering mutations in the broader social and economic spheres with the latter, in my mind, taking precedence. Namely, in bygone times, the time of retirement meant exactly what the word denotes, a period when one retires from the wheels of the economy and enjoys the fruits of his or her labor. By all accounts, under the dictate of money, which I think succinctly explains the present conjuncture, this seems to be an unaffordable luxury. Retirement in the time of neoliberalism, to give this mutation a name, is marked by a shift which Carolyn Hardin succinctly describes as follows:

The decline of traditional pensions and the rise of individualized retirement accounts such as $401(\mathrm{k}) \mathrm{s}$ can be read as a neoliberal program of transferring risk and responsibility for providing retirement income from employers to workers and producing workers as self-provisioning employee-investor subjects. (95)

Traditional pensions and the new schemes differ in designating who is responsible for their funding and management. Put otherwise, instead of the older system where pensions were seen as a reward for a lifetime of labor, a reward that was systematically built up through subtractions from wages, pensions are now seen as resources for finance and investment. A period of the life span that was seen as unproductive is now again reincorporated into the process of augmenting profits, producing a specific subject. Although retired from the process of production, that subject, the pensioner is not given free reign but is objectified as a resource for accumulation and profit. Capital reaches out from the cradle to the grave.

For an explanation of how I use the word in discussing the plight of the humanities, see: Grgas, Stipe. "The Unsolicited Labor of the Humanities." English Studies from Archives to Prospects, edited by Stipe Grgas, Tihana Klepač, and Martina Domines Veliki, Cambridge Scholars Publishing, 2016, pp. 163-178. 
The size of the financial value that pension funds have at their disposal has prompted some observers, such as Gordon Clark, to coin the phrase "pension fund capitalism" (Clark 2000). ${ }^{2}$ The implications of this development, how it functions within the financialized condition of the world economy, are matters that do not directly interest me here. I return to the particularism of American Studies and ask whether the cooption of pensions by investment, and I believe this is the bottom line of the development, evinces any American peculiarities. In her article "The Time of Money in Finance and U.S. Society," Elena Esposito counter-positions the temporalities of Europe and of the United States. She writes that in Europe you tend to go from the present to the future wherein the future is a result of the past and the path that led to the present. The possibilities that lie before one depend on that path and are curtailed by the weight of the past. In Esposito's opinion, the United States espouses a different temporality:

In the US, you go from the future to the present. The sense of the present is the result of a projection of the future, on which the interpretation and evaluation of the past depends. The sense of the present is "colonized" by the construction of the future: decisions in the present depend on the future that one wants to build, and the available possibilities will be defined accordingly. (21-2)

The shift in American pension funds that I have remarked upon, the evisceration of the value of past contributions to pension funds, parallels this debasement of the past and the privileging of the future. However, if the imperative to invest infringes upon entitlements and marks a downgrading of the quality of retirement, this is a benign development in comparison to the growing possibility that in parts of the world the very future of pensions is at stake.

I am writing from a country where this seems to be the future. Politicians announce that the very notion of pension is something that should not be taken for granted, that pensions are a relic of a bygone time. If, returning to my opening remarks, we contextualize both age and retirement into history, this ought not to be viewed as something unprecedented. I again return to Carolyn Hardin's article:

Critiques of neoliberalism as the breakdown of the Fordist compromise can invoke nostalgia for a golden age of capitalism in which worker se- 
curity was completely assured, but in fact, retirement is a relatively new phenomenon, one created by the institutions of Social Security and government-incentivized private pensions after the Great Depression. (100)

\section{Conclusion}

I conclude that nostalgia for a golden age ought not to be restricted to the capitalist order. On the contrary, I am of the opinion that many humanizing developments within capitalism were due to the presence of an alternative option that propagated the life-long interests of the working class. This is not the place to elaborate upon this, but it suffices to say that in the social order that legitimated itself as socialist, pensions were deemed all but sacrosanct. In other words, a progressivist political option valorized past labor in absolute terms and not in terms of what future financial yield accrued to that past labor. Of course, even bringing up this issue in the post-socialist context antagonizes those who have made up their minds about the inevitable bankruptcy of the former system. To them, any mention of security or generational solidarity is anathema. I conclude on this note to signalize that not only am I growing obsolete in a historical juncture of capitalism triumphant but that a recollection of a different valorization of ageing in a different juncture makes me doubly so.

\section{Works Cited}

Baars, Jan. "Philosophy of Aging, Time, and Finitude." A Guide to Humanistic Studies in Ageing, edited by T.R. Cole, R. Ray, and R. Kastenbaum, John Hopkins UP, 2010, pp. 105-20. https://www.google.com/url?sa=t\&rct=j\&q=\&esrc=s\&source=web\&cd=2\&ved=2ahUKEwj98J-7l-3lAhUHposKHY2DAEYQFjABegQIARAC\&url=https\%3A\%2F\%2Frepository.uvh.nl\%2Fuvh\%2Fbitstream\%2Fhandle\%2F11439\%2F243\%2FHopkins\%2520Handbook\%2520Chapter\%25204\%2520def.doc\%3Fsequence\%3D1\&usg=AOvVaw25OQz50zaT9UA91JFZTRKJ. Accessed 30 May 2019.

Castillo Street, Susan. "Facing Whiteness: The Perdurability of Race in US Writing." "Forever Young"? The Changing Images of America, edited by Philip Coleman and Stephen Matterson, Universitätsverlag Winter, 2012, pp. 119-30.

Clark, Gordon. Pension Fund Capitalism. Oxford UP, 2000.

Connerton, Paul. How Modernity Forgets. Cambridge UP, 2009.

Crary, Jonathan. 24/7: Late Capitalism and the Ends of Sleep. Verso, 2014.

Eggers, Dave. A Hologram for the King. McSweeney's Books, 2012.

Esposito, Elena. "The Time of Money in Finance and US Society." Finance and Society, vol. 4, no. 1, 2018, pp. 15-25. 
Grgas, Stipe. “The Unsolicited Labor of the Humanities." English Studies from Archives to Prospects, edited by Stipe Grgas, Tihana Klepač, and Martina Domines Veliki, Cambridge Scholars Publishing, 2016, pp. 163-178.

Hardin, Carolyn. "Neoliberal Temporality: Time-Sense and the Shift from Pensions to 401(k)s." American Quarterly, vol. 66, no. 1, 2014, pp. 95-118.

Hartung, Heike, and Rüdiger Kunow. "Introduction: Age Studies." Amerikastudien/American Studies, vol. 56, no. 1, 2011, pp. 15-22.

Hassan, Ihab. Radical Innocence: Studies in the Contemporary Novel. Harper and Row, 1961.

Illych, Ivan. "Vernacular Values." Davidtinapple.com, http://www.davidtinapple.com/illich/1980_vernacular_values.html. Accessed 13 March 2019.

Lewis, R.W.B. The American Adam: Innocence, Tragedy and Tradition in the Nineteenth Century. Phoenix Books, 1959.

May, Jon, and Nigel Thrift. "Introduction.” Timespace: Geographies of Temporality, edited by Jon May and Nigel Thrift, Routledge, 2011, pp. 1-46.

Rushdie, Salmon. The Golden House. Jonathan Cape, 2017.

Sewell, William H. Jr. “The Temporalities of Capitalism.” Socio-Economic Review, vol. 6, no. 3, 2008, pp. 517-37.

Toh, Justine. "Bar(r)ack(ing) for Change: Obama as the Latest American Adam.” Publicchristianity.com, www.publicchristianity.com/Obamaadami.html. Accessed 5 May 2019.

Wolff, Michael. Fire and Fury: Inside the Trump White House. Henry Holt and Company, 2018.

Zehelein, Eva-Sabine. “Whatever Senior Living Choice or Lifestyle Option You Desire, You're Sure to Find It': 55+, Age Segregation and the American Social Landscape." "Forever Young"? The Changing Images of America, edited by Philip Coleman and Stephen Matterson, Universitätsverlag Winter, 2012, pp. 21-42. 


\section{ISTOSTI I RAZLIKE STARENJA}

\section{Sažetak}

\begin{tabular}{c}
\hline Stipe GRGAS \\
Filozofski fakultet \\
Sveučilišta u Zagrebu \\
Ivana Lučića 3, HR - 10 000 Zagreb \\
sgrgas@ffzg.hr \\
\hline
\end{tabular}

Koliko god je starenje univerzalna kategorija autor ukazuje na činjenicu da taj proces nije podjednako registriran u različitim kulturama. Pišući iz perspektive američkih studija i stavljajući poseban naglasak na sintagmu „američki Adam“ C. S. Lewisa, autor članka ukazuje na osebujan način kako američke identitetske strategije tretiraju starost kao nešto strano naciji koja se poima kao „uvijek mlada“ zemlja. U daljnjoj raspravi ukazuje se na međuuvjetovanost takvog poimanja ljudskog trajanja i američkog ekonomskog ustroja i kako se sve to odražava na procese u američkoj suvremenosti.

Ključne riječi: starenje, američki studiji, američki Adam, mladost, Trump, R. W. B. Lewis 